\title{
Quality characteristics and processing of rice cake (Backsulgi) with rice flour containing Lactobacillus plantarum CGKW3 by spray-drying
}

\author{
Dae-Hoon Lee, Hye-Mi Park, Joo-Heon Hong* \\ Department of Food Science and Technology, Catholic University of Daegu, Gyeongsan 38430, Korea
}

\section{유산균 포집 쌀가루를 이용한 백설기의 제조 및 품질특성}

\author{
이대훈 · 박혜미 · 홍주헌* \\ 대구가톨릭대학교 식품공학전공
}

\begin{abstract}
The quality characteristics and processing of rice cake (Backsulgi) with rice flour containing Lactobacillus plantarum CGKW3 by spray-drying (LP-B) were investigated. The LP-B was applied at ratios of 10, 20, and 30 (w/w), and the moisture contents and $\mathrm{pH}$ were $33.39 \%-36.70 \%$ and $5.81 \sim 5.46$, respectively. The $\mathrm{L}$ value of $\mathrm{LP}-\mathrm{B}$ increased as the rice flour decreased, while the a and $b$ value increased as the LP-B increased. The texture profiles showed that Backsulgi prepared with LP-B mixture had higher hardness, cohesiveness, springiness and chewiness than $100 \%$ rice flour. The $\mathrm{pH}$ of LP-B Backsulgi (LP-B20 and LP-B30) did not differ during 6 days at room temperature. The total bacteria in Backsulgi prepared LP-B20 and LP-B30 Backsulgi was $10^{4}$ CFU/g after 2 days of storage at room temperature. The shelf life of Backsulgi prepared with LP-B20 and LP-B30 were extended by about 2 days when compared with the control at room temperature. Sensory evaluation showed that Backsulgi without LP-B20 had higher scores in terms of appearance, color, flavor, taste, texture, hardness and overall acceptability than Backsulgi without $100 \%$ rice flour. In conclusion, the results demonstrate that LP-B20 may prove quite useful as a Backsulgi flour with desirable properties.
\end{abstract}

Key words : Backsulgi, Lactobacillus plantarum CGKW3, spray drying, quality characteristics, storage stability

\section{서 론}

쌀은 세계 주요 국가에서 주식으로 이용되고 있으며, 특 히 동남아를 비롯해 우리나라 국민의 주요 주식원으로 사용 되고 있다(1). 최근, 경제 발전에 힘입어 식생활에서 쌀을 이용한 쌀 가공식품의 소비가 늘어나고 있으며 고령화 시대 및 핵가족화 추세에 맞추어 쌀의 소비형태도 편의식을 선호 하는 경향으로 변화되고 있다(2).

떡을 제조하는 방법은 다양한데 찌는 떡에 속하는 백설 기는 설기떡 중에서 가장 먼저 만들어진 떡의 기본형으로

*Corresponding author. E-mail : jhhong@cu.ac.kr Phone : 82-53-850-3218, Fax : 82-53-850-3218

Received 21 November 2016; Revised 21 December 2016; Accepted 21 December 2016.

Copyright (c) The Korean Society of Food Preservation. All rights reserved.
멥쌀 입자의 독특한 물성과 단맛이 어우러져 특유의 떡 맛을 내고 있어 많은 사람들이 즐겨 먹고 각종 행사에도 쓰이고 있다(3). 이렇듯 떡은 우리나라 고유의 전통음식 중의 하나이지만, 현대에 와서 식생활의 서구화와 제조방 법의 어려움, 그리고 쉽게 노화되는 단점 등으로 인해 대중 화 및 상품화에 어려움을 겪고 있어(4), 전통음식이 편의 식품화 되기 위해 개선해야 할 사항으로 위생과 저장성이 지적되고 있다(5). 떡은 전분질 식품인 곡류로부터 호화과 정을 거쳐 제조하기 때문에 일정 기간은 그대로 먹을 수 있는 식품이지만 상당한 수분을 함유하고 있어 저장동안 건조와 전분의 노화로 인해 단단해지는 결점이 있는 동시에 미생물이 발육하여 먹을 수 없게 되는 문제점을 가지고 있다(6). 이로 인해 식품의 보존을 위한 여러 가지 물리·화 학적인 방법들이 사용되고 있으나, 최근 소비자들은 신선 하고 최소한의 가공과 화학 첨가물이 들어 있지 않은 유통 기간이 연장된 식품을 요구하고 있다(7,8). 
김치 및 각종 장류 등과 같은 전통 발효식품 및 유제품에 함유된 유산균은 오래전부터 섭취되어 온 GRAS(generally recognizied as safe) 미생물로 안전하며, 산업적으로 빈번하 게 이용되고 있다(9). 일반적으로 품질증가, 식품보존 작용, 장내 유해균 억제 작용, 정장작용 및 면역증강 효과 등의 다양한 생리활성을 가지고 있으며 $(10,11)$, 이 중 유산균의 식품보존 작용은 유산균이 생산하는 유기산에 의한 $\mathrm{pH}$ 저 하, $\mathrm{H}_{2} \mathrm{O}_{2}, \mathrm{CO}_{2}$, diacetyl 및 bacteriocin 등 항균활성 물질의 생산으로 유해 미생물을 사멸시키거나 생육을 억제하는 작용을 하여 식품의 저장성과 안전성에 기여하고 있다(12). 국내에서는 백설기에 천연항균제제(4), bacterial cellulose(6), 고구마(13) 및 트레할로스(14) 등을 첨가하여 품질특성 및 저장에 대해 보고된 바 있다.

따라서 본 연구에서는 김치로부터 분리된 유산균인 Lactobacillus plantarum CGKW3을 배양한 다음 분무건조 공정으로 유산균을 쌀가루에 포집하여 분말화 하였으며 제조된 유산균 포집 쌀가루를 이용하여 백설기 제조에 첨가 한 다음 다양한 품질특성 및 저장안정성을 조사하였고 떡의 대중화 및 상품화를 위한 기초자료를 제공하고자 하였다.

\section{재료 및 방법}

\section{유산균 배양}

유산균 배양액은 김치로부터 분리한 Lactobacillus plantarum CGKW3(KACC92075P)을 사용하였으며, 균주 의 배양을 위한 배지(sucrose $20 \mathrm{~g}$, skim milk $10 \mathrm{~g}$, yeast extract $10 \mathrm{~g}, \mathrm{~K}_{2} \mathrm{HPO}_{4} 2 \mathrm{~g}$, sodium citrate $10 \mathrm{~g}, \mathrm{MgSO}_{4} 2$ $\mathrm{g}$ 을 증류수 $1 \mathrm{~L}$ 에 용해)를 제조 한 다음 액체 종균 $3 \%$ 를 접종하고 $37^{\circ} \mathrm{C}$ 에서 24 시간동안 정치배양(IL-21, Jeio tech., Daejeon, Korea) 하였다.

\section{유산균 포집 쌀가루 제조}

쌀가루는 국내산으로 농업회사법인 (주)영풍(Daegu, Korea) 에서 제공받은 것을 $60 \mathrm{mesh}$ 표준망체 $(0.25 \mathrm{~mm}$, Chunggye, Seoul, Korea)에 통과시킨 뒤, Autoclave(HB-506-4, Hanbaek Sci Co., Bucheon, Korea)로 $121^{\circ} \mathrm{C}, 1.2$ 기압에서 15 분동안 처리한 다음 유산균 포집을 위한 피복물질로 사용하였다.

분무건조에 의한 유산균포집 쌀가루 제조를 위해 유산균 배양액 대비 $50 \%(\mathrm{w} / \mathrm{v})$ 의 쌀가루를 첨가하여 교반한 다음 atomizer가 장착된 분무건조기(KL-8, Seogang engineering Co., Ltd., Cheonan, Korea)를 이용하여 inlet temperature $160^{\circ} \mathrm{C}$, outlet temperature $100^{\circ} \mathrm{C}$ 로 설정하였고, atomizer speed 17,000 rpm에서 시료 공급속도는 $12 \mathrm{~mL} / \mathrm{min}$ 의 조건 으로 제조하였으며, $-70^{\circ} \mathrm{C}$ 이하 냉동고에 보관하면서 분석 용 시료로 사용하였다. 대조구로는 증류수에 쌀가루를 첨 가하여 교반 한 다음 분무건조한 분말을 사용하였다.

\section{백설기의 제조}

유산균포집 쌀가루를 혼합한 백설기의 재료 배합비는 Table 1과 같다. 백설기에 들어가는 유산균 포집 쌀가루 첨가량을 정하기 위해 예비 실험을 거쳐 재료 전체의 $10 \%$, $20 \%$ 및 $30 \%$ 의 수준으로 유산균 포집 쌀가루를 무처리 쌀가 루 함량과 대체 하였으며, 쌀가루 대비 설탕(Samyang Co., Seoul, Korea) $10 \%$, 정제소금(CJ Cheiljedang Co., Seoul, Korea) $1 \%$ 및 증류수 50\%(w/v)를 첨가한 다음 20 mesh 표준망체(0.84 mm, Chunggye)에 통과시켜 백설기 제조에 사용하였다. 백설기의 제조는 지름 $25 \mathrm{~cm} \times 25 \mathrm{~cm}$ 의 stainless steel 시루 안에 젖은 면 보자기를 깔고 혼합한 재료를 넣어 $4 \mathrm{~cm}$ 두께가 되도록 위를 평평하게 하여 젖은 면 보자기를 덮은 후 찜통(GRA-SD203C, Tongyang/Magic Co., Seoul, Korea)에 증기가 오르면 20 분간 찐 다음 10 분간 뜸을 들이 는 방법으로 제조하였으며, 실온에서 10 분간 방냉한 다음 실험용 시료로 사용하였다.

Table 1. Formulation of rice cake (Backsulgi) added with different concentrations of $L$. plantarum CGKW3 by spray drying

\begin{tabular}{cccccc}
\hline Samples $^{1)}$ & Rice flour & $\begin{array}{c}\text { Spray-dried } \\
\text { powder }\end{array}$ & Water & Sugar & Salt \\
\hline NTS & 300 & 0 & 150 & 30 & 3 \\
Con & 0 & 300 & 150 & 30 & 3 \\
LP-B10 & 270 & 30 & 150 & 30 & 3 \\
LP-B20 & 240 & 60 & 150 & 30 & 3 \\
LP-B30 & 210 & 90 & 150 & 30 & 3 \\
\hline
\end{tabular}

${ }^{11} \mathrm{NTS}$, rice flour $100 \%$; Con, spray-dried rice flour $100 \%$; LP-B10, add with rice flour included $L$ plantarum CGKW3 by spray-drying 10\%; LP-B20, add with rice flour included $L$ plantarum CGKW3 by spray-drying 20\%; LP-B30, add with rice flour included $L$ plantarum CGKW3 by spray-drying $30 \%$.

\section{수분함량 및 $\mathrm{pH}$ 측정}

수분함량은 백설기 $1 \mathrm{~g}$ 을 적외선 수분측정기(MB-45, Moisture analyzer, INC., Ohaus, NJ, USA)를 이용하여 $105^{\circ} \mathrm{C}$ 에 서 수분함량이 항량에 도달할 때까지 건조하여 측정하였다.

$\mathrm{pH}$ 측정은 시료 $1 \mathrm{~g}$ 에 증류수 $9 \mathrm{~mL}$ 를 혼합하여 1 분간 균질한 후 $\mathrm{pH}$ meter(Mettler toledo Instruments Ltd., Langacher, Switzerland)로 상온에서 측정하였다.

\section{색도 측정}

색도 측정은 백설기를 표준색도가 $\mathrm{L}=94.5, \mathrm{a}=0.18$, $\mathrm{b}=0.32$ 로 보정된 색차계(Chromameter CR300, Minolta Co, Osaka, Japan)를 사용하여, 명도를 나타내는 L*(lightness), 적색도를 나타내는 $\mathrm{a}^{*}$ (redness), 황색도를 나타내는 $\mathrm{b}^{\star}$ (yellowness)값을 측정하였으며, 색차 $\Delta \mathrm{E}$ 는 아래와 같이 계산하였다. 
$\Delta \mathrm{E}=\sqrt{\Delta L^{2}+\Delta a^{2}+\Delta b^{2}}$

\section{기계적 조직감 측정}

백설기의 조직감은 rheometer(COMPAC-100, Sun scientific Co., Tokyo, Japan)를 이용하여 분석하였다. 백설기를 $25 \times$ $25 \times 25 \mathrm{~mm}$ 의 크기로 자른후 hardness(견고성), cohesiveness (응집성), springiness(탄력성), chewiness(씹힘성)를 측정하 였다. 이때, rheometer 측정 조건은 최대 하중 $2 \mathrm{Kg}$, probe distance $5.00 \mathrm{~mm}$, table speed $50 \mathrm{~mm} / \mathrm{min}$ 및 distance $30 \%$ 였 으며, 모든 시료는 10 회 반복 측정하여 평균값 \pm 표준 편차로 나타내었다.

\section{저장안정성 및 미생물 안전성 평가}

저장안정성 및 미생물 안전성을 평가하기 위해 백설기를 실온에서 30 분간 냉각 한 다음, $25 \times 25 \times 25 \mathrm{~mm}$ 로 잘라 polyethylene film bag에 밀봉하여 $25^{\circ} \mathrm{C}$ 에서 6 일간 저장하였 다. 저장안정성은 시료 $1 \mathrm{~g}$ 에 증류수 $9 \mathrm{~mL}$ 를 혼합하여 1 분 간 균질한 후 $\mathrm{pH}$ meter(Mettler toledo Instruments Ltd.)로 측정하였으며, 미생물 안전성은 시료 $1 \mathrm{~g}$ 에 $0.85 \%$ sodium chloride 용액(w/v, Duksan pure chemicals Co., Ltd.) $9 \mathrm{~mL}$ 를 첨가하여 10 배 희석법으로 희석한 다음 각각의 희석액 100 $\mu \mathrm{L}$ 를 plate count agar(Difico Co., Detroit, MI, USA)배지에 접종하여 평판 측정법으로 일반세균을 측정하였다. 각각의 plate는 $37^{\circ} \mathrm{C}$ 에서 24 시간 배양한 다음 형성된 colony 수를 계측하고, colony에 희석배수를 곱하여 시료 $\mathrm{g}$ 당 $\mathrm{CFU}$ (colony forming unit)로 나타내었다. 곰팡이의 형성은 육안 으로 디지털 사진기(Powershot S5 IS, Canon, Tokyo, Japan) 를 이용하여 같은 장소, 조명에서 시료와 사진기의 거리 및 높이는 일정하게 유지하고 플래시가 터지지 않도록 촬영 하였다.

\section{관능검사}

백설기의 관능검사는 30 명의 훈련된 평가원을 대상으로 7점 척도(1, 대단히 싫어함; 7 , 대단히 좋아함)를 사용하여 평가하였다. 평가 항목은 appearance(외관), color(색), flavor(향미), taste(맛), texture(조직감), hardness(딱딱함) 및 overall preference(전체적 기호도) 였으며, 정확한 결과를 위해서 각 시료간 물을 이용하여 입안을 헹구고 충분한 시간 간격을 두고 검사를 실시하였다.

\section{통계처리}

모든 실험결과는 3회 반복하여 실시하였고 그 결과 값을 평균표준편차로 나타내었으며 SPSS(19.0, SPSS Inc., Chicago, IL, USA)를 이용하여 분산분석(ANOVA)과 Duncan's multiple range test $(\mathrm{p}<0.05)$ 를 실시하였다.

\section{결과 및 고찰}

\section{수분함량 및 $\mathrm{pH}$}

분무건조 공정을 이용하여 제조된 유산균포집 쌀가루의 유산균수는 $7.57 \log \mathrm{CFU} / \mathrm{mL}$ 였고, $\mathrm{pH}$ 및 산도는 각각 4.97 및 $0.19 \%$ 를 나타내었다. 유산균 포집 쌀가루 첨가량에 따른 백설기의 수분함량 및 $\mathrm{pH}$ 는 Table 2 에 나타내었다.

백설기의 수분함량은 유산균 포집 쌀가루 첨가량이 증가 함에 따라(LP-B10 LP-B30, 유산균 포집 쌀가루 10 30\%) 33.39 36.70\%로 증가하는 경향을 나타내었으며, NTS(무 처리 쌀가루 $100 \%$ ) 및 $\operatorname{Con}$ (분무건조 쌀가루 $100 \%$ )에서 각각 $34.84 \%$ 및 $30.68 \%$ 의 함량을 나타내었다. 이는 Con의 수분함량이 NTS보다 낮게 함유되어 있어 백설기 제조시 전분의 호화에 필요한 수분이 부족하여 호화를 방해하는 동시에 가열로 인한 응고성이 커지므로 백설기의 수분함량 이 낮게 나타난 것으로 사료된다. Shim 등(15)의 Lactobacillus delbrückir를 첨가한 식빵의 품질연구에서 유산균이 첨가된 sourdough를 이용한 식빵이 일반 식빵에 비해 보수력 증가 효과가 있다고 보고하였다. 또한, Seibel 와 Brummer(16)의 독일의 sourdough 빵 제조 연구에서 유산균 포집에 의해 $\mathrm{pH}$ 가 저하되고 원료 쌀가루의 단백질과 탄수화물의 수화 및 팽창을 촉진시켜 보수력 증가를 통한 탄수화물의 효소 분해 억제로 탄력성을 증가시켜 준다고 보고하였다.

Table 2. Moisture contents and $\mathrm{pH}$ of rice cake (Backsulgi) added with different concentrations of $L$. plantarum CGKW3 by spray-dried powder

\begin{tabular}{ccc}
\hline Samples $^{1)}$ & Moisture content $(\%)$ & $\mathrm{pH}$ \\
\hline NTS & $34.84 \pm 0.04^{\mathrm{b} 2)}$ & $6.13 \pm 0.01^{\mathrm{b}}$ \\
Con & $30.68 \pm 0.40^{\mathrm{d}}$ & $6.17 \pm 0.01^{\mathrm{a}}$ \\
LP-B10 & $33.39 \pm 0.31^{\mathrm{c}}$ & $5.86 \pm 0.01^{\mathrm{c}}$ \\
LP-B20 & $34.54 \pm 0.15^{\mathrm{b}}$ & $5.64 \pm 0.01^{\mathrm{d}}$ \\
LP-B30 & $36.70 \pm 1.10^{\mathrm{a}}$ & $5.46 \pm 0.01^{\mathrm{e}}$ \\
\hline
\end{tabular}

${ }^{1)}$ NTS, rice flour 100\%; Con, spray-dried rice flour 100\%; LP-B10, add with rice flour included $L$ plantarum CGKW3 by spray-drying 10\%; LP-B20, add with rice flour included $L$ plantarum CGKW3 by spray-drying 20\%; LP-B30, add with rice flour included $L$ plantarum CGKW3 by spray-drying $30 \%$.

${ }^{2)}$ Means $\pm \mathrm{SD}$ (n=3) within each column (a-e) followed by the same letter are not significantly different $(\mathrm{p}<0.05)$.

$\mathrm{pH}$ 는 유산균 포집 쌀가루 첨가량이 $10 \%, 20 \%$ 및 $30 \%$ 로 증가함에 따라 $\mathrm{pH}$ 5.86에서 5.46으로 유의적으로 저하되었 으며, 무처리군 및 증류수에 쌀가루를 첨가하여 분무건조 한 대조군은 각각 $\mathrm{pH} 6.13$ 및 $\mathrm{pH} 6.17$ 로 나타났다. Cha 등(17)은 Lactobacillus acidophilus를 배양한 밀가루 발효물 면(noodles)의 $\mathrm{pH}$ 에서 발효물 첨가량이 $20 \%$ 로 증가함에 따라 $\mathrm{pH}$ 6.01에서 $\mathrm{pH}$ 4.03으로 저하되는 경향을 나타내었 는데, 이는 유산균 발효물의 유기산에 의한 것으로 본 연구 에서도 유사한 경향을 나타내었다. 이는 본 연구결과에서 
도 유산균 포집 쌀가루의 첨가를 통한 $\mathrm{pH}$ 저하 및 보수력 증가로 백설기의 식감 개선이 가능할 것으로 사료된다.

\section{색 도}

유산균 포집 쌀가루 첨가량에 따른 백설기 색도를 측정 한 결과는 Table 3에 나타내었다. 색도는 NTS에서 L값, $\mathrm{a}$ 값 및 $\mathrm{b}$ 값이 각각 $87.66,-1.29$ 및 7.91을 나타내었으며, L값은 Con에서 90.01로 가장 높고 LP-B30에서 82.96으로 가장 낮게 나타났다. $\mathrm{a}$ 값 및 $\mathrm{b}$ 값은 유산균 포집 쌀가루 첨가 량이 증가함에 따라 각각 -0.87 -0.50 및 9.75 12.83으로 증가하는 경향을 나타내었다. 특히 NTS를 기준으로 유산균 포집 쌀가루 첨가량 증가에 따른 $\triangle \mathrm{E}$ 값은 LP-B10에서 3.66 로 색의 변화가 가장 낮았고, LP-B30에서 6.85로 가장 높은 변화를 나타내었다. 이는 Cha 와 Lee (18)의 Lactobacillus acidophilus로 발효시킨 밀가루 발효물 반죽의 총 색도 값이 대조구 보다 높았다고 보고하였으며, Chang 등(19)의 유산 발효 쌀가루의 혼합비율에 따른 전(Jeon)의 색도에서 유산 발효 쌀가루의 혼합 비율이 증가할수록 전의 L값은 감소하 고 $\mathrm{a}$ 값 및 $\mathrm{b}$ 값은 증가한다고 보고하여, 본 연구 결과와 유사 한 경향을 나타내다. 이는 유산균 배양액 포집에 따른 쌀가 루의 색도 변화에 의해 백설기 제조시 색의 변화가 나타나 는 것으로 사료된다.

Table 3. Hunter color value of rice cake (Backsulgi) added with different concentrations of $L$ plantarum CGKW3 by spray drying

\begin{tabular}{ccccc}
\hline Samples $^{1)}$ & $\mathrm{L}$ & $\mathrm{a}$ & $\mathrm{b}$ & $\triangle \mathrm{E}$ \\
\hline NTS & $87.66 \pm 0.80^{\mathrm{b} 2)}$ & $-1.29 \pm 0.04^{\mathrm{d}}$ & $7.91 \pm 0.14^{\mathrm{d}}$ & - \\
Con & $90.01 \pm 0.62^{\mathrm{a}}$ & $-0.87 \pm 0.02^{\mathrm{c}}$ & $8.34 \pm 0.12^{\mathrm{d}}$ & $2.43 \pm 0.60^{\mathrm{c}}$ \\
LP-B10 & $86.08 \pm 0.11^{\mathrm{c}}$ & $-0.87 \pm 0.02^{\mathrm{c}}$ & $9.75 \pm 0.51^{\mathrm{c}}$ & $3.66 \pm 0.16^{\mathrm{b}}$ \\
LP-B20 & $83.38 \pm 0.95^{\mathrm{d}}$ & $-0.70 \pm 0.17^{\mathrm{b}}$ & $11.17 \pm 0.15^{\mathrm{b}}$ & $4.67 \pm 1.05^{\mathrm{b}}$ \\
LP-B30 & $82.96 \pm 0.52^{\mathrm{d}}$ & $-0.50 \pm 0.01^{\mathrm{a}}$ & $12.83 \pm 0.14^{\mathrm{a}}$ & $6.85 \pm 0.45^{\mathrm{a}}$ \\
\hline
\end{tabular}

${ }^{11}$ NTS, rice flour $100 \%$; Con, spray-dried rice flour $100 \%$; LP-B10, add with rice flour included $L$ plantarum CGKW3 by spray-drying $10 \%$; LP-B20, add with rice flour included $L$ plantarum CGKW3 by spray-drying 20\%; LP-B30, add with rice flour included $L$ plantarum CGKW3 by spray-drying $30 \%$.

${ }^{2)}$ Means \pm SD (n=3) within each column (a-d) followed by the same letter are not significantly different $(\mathrm{p}<0.05)$.

\section{기계적 조직감}

유산균 포집 쌀가루 첨가량에 따른 백설기의 기계적 조 직감을 측정한 결과는 Table 4에 나타내었다. 경도 (hardness)는 유산균 포집 쌀가루 첨가량이 증가할수록 $931.37 \sim 1,222.67 \mathrm{~g} / \mathrm{cm}^{2}$ 로 Con의 $867.70 \mathrm{~g} / \mathrm{cm}^{2}$ 및 NTS $999.70 \mathrm{~g} / \mathrm{cm}^{2}$ 에 비해 경도가 증가하였다. Yoon(20)의 연잎 가루를 첨가한 백설기 제조 연구에서 경도는 떡의 품질 평가에 가장 중요한 요소로 주로 수분 함량과 관련이 있다 고 보고하였다. 이는 본 연구결과에서 유산균 포집 쌀가루 첨가에 의해 백설기의 수분 보수력 증가로 Con에 비해 경도 가 증가하는 경향을 나타내었다. 응집성(cohesiveness) 및 탄력성(springiness)은 유산균 포집 쌀가루 첨가량이 증가함 에 따라 각각 8.96 10.58\% 및 31.41 34.48\%로 Con 구간의 $6.72 \%$ 및 $25.61 \%$ 에 비해 백설기의 응집성 및 탄력성이 증 가하였다. 씹힘성(chewiness)은 유산균 포집 쌀가루 첨가량 증가에 따라 42.46 62.37 g으로 Con 구간의 $28.72 \mathrm{~g}$ 에 비해 증가하는 경향을 나타내었다. 유산균 포집 쌀가루는 증류 수에 쌀가루를 첨가하여 분무건조 한 Con에 비해 백설기의 조직감이 NTS와 유사하거나 개선되는 효과를 나타내었다. 백설기 자체는 탄성의 변화가 적은 시료임에도 불구하고 탄력성 및 내부 결합력인 응집성이 증가하였으며(21), LP-B20에서 NTS군과 기계적 조직감이 매우 유사한 경향을 나타내어 향후 조직감이 개선된 백설기를 제조할 수 있을 것으로 사료된다.

Table 4. Texture profile analysis parameters of rice cake (Backsulgi) added with different concentrations of $L$. plantarum CGKW3 by spray drying

\begin{tabular}{ccccc}
\hline \multirow{2}{*}{ Samples 1$)$} & \multicolumn{4}{c}{ Textural property } \\
\cline { 2 - 5 } & $\begin{array}{c}\text { Hardness } \\
\left(\mathrm{g} / \mathrm{cm}^{2}\right)\end{array}$ & $\begin{array}{c}\text { Cohesiveness } \\
(\%)\end{array}$ & $\begin{array}{c}\text { Springiness } \\
(\%)\end{array}$ & $\begin{array}{c}\text { Chewiness } \\
(\mathrm{g})\end{array}$ \\
\hline NTS & $999.70 \pm 19.29^{\mathrm{c} 2)}$ & $9.53 \pm 0.51^{\mathrm{ab}}$ & $32.29 \pm 0.89^{\mathrm{a}}$ & $48.68 \pm 2.56^{\mathrm{b}}$ \\
Con & $867.70 \pm 7.99^{\mathrm{e}}$ & $6.72 \pm 1.15^{\mathrm{c}}$ & $25.61 \pm 3.47^{\mathrm{b}}$ & $28.72 \pm 7.14^{\mathrm{c}}$ \\
LP-B10 & $931.37 \pm 8.25^{\mathrm{d}}$ & $8.96 \pm 0.66^{\mathrm{b}}$ & $31.41 \pm 1.00^{\mathrm{a}}$ & $42.46 \pm 3.26^{\mathrm{b}}$ \\
LP-B20 & $1,023.67 \pm 16.77^{\mathrm{b}}$ & $9.35 \pm 0.44^{\mathrm{ab}}$ & $33.47 \pm 1.04^{\mathrm{a}}$ & $47.29 \pm 2.80^{\mathrm{b}}$ \\
LP-B30 & $1,222.67 \pm 7.51^{\mathrm{a}}$ & $10.58 \pm 0.29^{\mathrm{a}}$ & $34.48 \pm 0.97^{\mathrm{a}}$ & $62.37 \pm 7.32^{\mathrm{a}}$ \\
\hline
\end{tabular}

${ }^{11} \mathrm{NTS}$, rice flour $100 \%$; Con, spray-dried rice flour $100 \%$; LP-B10, add with rice flour included $L$ plantarum CGKW3 by spray-drying $10 \%$; LP-B20, add with rice flour included $L$ plantarum CGKW3 by spray-drying $20 \%$; LP-B30, add with rice flour included $L$ plantarum CGKW3 by spray-drying $30 \%$.

${ }^{2)}$ Means \pm SD ( $\mathrm{n}=3$ ) within each column (a-e) followed by the same letter are not significantly different $(\mathrm{p}<0.05)$.

\section{저장안정성}

백설기의 저장안정성은 유산균 포집 쌀가루를 첨가하여 백설기를 제조 한 다음 실온에서 6일간 보존하며 $\mathrm{pH}$ 측정 결과를 Fig. 1에 나타내었다. 유산균 포집 쌀가루 첨가 백설 기의 저장기간별 $\mathrm{pH}$ 측정에서 LP-B20 및 LP-B30 구간에서 는 $\mathrm{pH}$ 의 유의적인 변화를 나타내지 않았다. 그러나 다른 모든 구간에서는 저장 4일까지 안정하였으나 4일 이후 백 설기의 $\mathrm{pH}$ 가 급격히 저하되는 경향을 나타내었다. 이는 백설기의 저장 중 균의 증식에 의한 백설기의 변패에 의해 $\mathrm{pH}$ 가 변화한 것으로 사료되며, Cha 등(15)의 Lactobacillus acidophilus를 배양한 밀가루면(noodles) 저장성 연구에서 면의 $\mathrm{pH}$ 변화는 4 일 저장 후 $\mathrm{pH}$ 가 다소 저하되었으나 그 이후부터는 큰 저하 없이 일정하게 유지되었다고 보고하 였다.

\section{미생물 안전성}

유산균 포집 쌀가루를 첨가하여 제조한 백설기의 미생물 


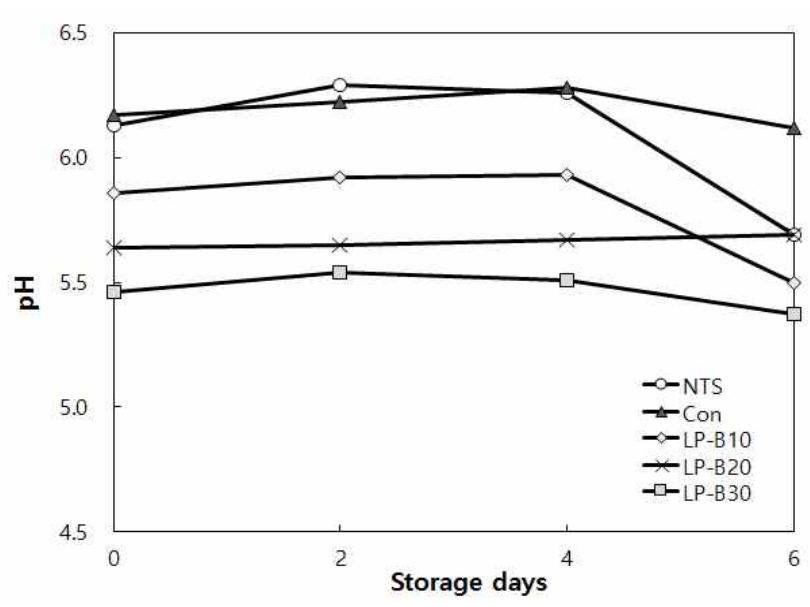

Fig. 1. Change in $\mathrm{pH}$ of rice cake (Baekseolgi) produced during the storage for 6 days at room temperature $\left(25^{\circ} \mathrm{C}\right)$.

NTS, rice flour 100\%; Con, spray-dried rice flour 100\%; LP-B10, add with rice flour included $L$ plantarum CGKW3 by spray-drying 10\%; LP-B20, add with rice flour included $L$ plantarum CGKW3 by spray-drying 20\%; LP-B30, add with rice flour included $L$ plantarum CGKW3 by spray-drying $30 \%$.

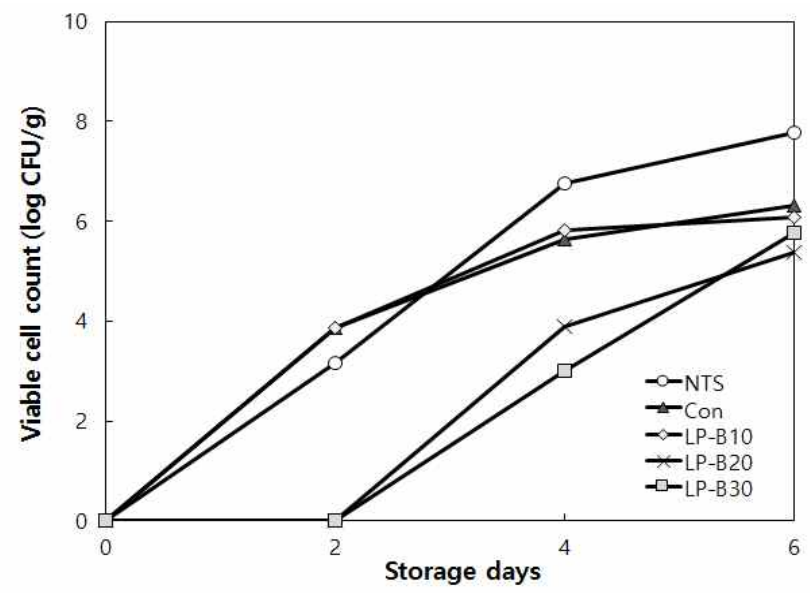

Fig. 2. Change in viable cell count of rice cake (Baekseolgi) produced during the storage for 6 days at room temperature $\left(25^{\circ} \mathrm{C}\right)$. NTS, rice flour 100\%; Con, spray-dried rice flour 100\%; LP-B10, add with rice flour included $L$ plantarum CGKW3 by spray-drying $10 \%$; LP-B20, add with rice flour included L. plantarum CGKW3 by spray-drying 20\%; LP-B30, add with rice flour included $L$ plantarum CGKW3 by spray-drying $30 \%$.
안전성은 실온에서 6일간 보존하며 일반세균 수 및 외관변 화 측정 결과를 Fig. 2 및 Fig. 3에 나타내었다. 일반세균수의 변화는 LP-B20 및 LP-B30의 경우 저장 2 일차까지 일반세 균의 생장을 나타내지 않아 시중에 판매되는 백설기(NTS) 대비 2일 이상의 미생물 안전성이 연장되는 효과를 나타내 었으며, LP-B10의 경우 저장 2 일차에 유해 미생물 수가 $4 \log \mathrm{CFU} / \mathrm{g}$ 이상 증가하여 낮은 안전성을 나타내었다. 특히 6일 동안 육안으로 관찰한 결과, 유산균 포집 쌀가루 첨가량 정도에 따라 곰팡이의 번식 정도를 확연히 알 수 있었다(Fig. 3). 최근 유산균을 이용한 빵의 보존법이 안전 한 대안으로 평가받고 있다(22). 이러한 유산균의 효과는 유기산, 지방산 및 펩타이드 등의 부산물에 의한 것으로 알려져 있으며(23), Choi 등(24)의 김치유산균으로 발효한 쌀가루의 유기산조성에서 lactic acid 함량 증가를 통해 저장 안전성 향상에 유리한 역할을 할 수 있을 것이라고 보고 하였다. 본 연구결과에서는 백설기를 제조한 다음 유산균 수 측정결과 모두 사멸함을 확인하였으며(data not shown), 이는 증기에 20 분간 찐 다음 10 분간 뜸을 들이는 과정에서 유산균이 사멸한 것으로 사료된다. 따라서, 유산균 포집 쌀가루를 이용한 백설기의 저장 안전성 향상은 유산균 포접 을 통한 유기산함량의 증가로 인한 $\mathrm{pH}$ 조절과 더불어 적절 한 수분함량이 중요한 요소라 판단된다. Kim과 Park (25)의 흰 절편 저장 연구에서 보통 포장하지 않은 절편은 $20^{\circ} \mathrm{C}$ 에 1 일간 보관하여도 미생물의 작용으로 변패가 일어나고 외 관으로 보아도 식용이 불가능하다고 보고하여, 유산균 포 집 쌀가루를 통해 제조된 백설기의 저장안정성의 개선을 확인할 수 있었다.

\section{관능평가}

유산균 포집 쌀가루를 첨가한 백설기의 관능평가를 외관 (appearance), 색(color), 향(flavor), 맛(taste), 조직감(texture), 단단한 정도(hardness) 및 전반적인 기호도(overall acceptability) 를 평가한 결과는 Table 5와 같다. 관능평가 결과 외관 및 색은 LP-B10에서 가장 높았으며, 대조구(Con) 및 LP-B30에

Table 5. Sensory evaluation results of rice cake (Backsulgi) added with different concentrations of $L$. plantarum CGKW3 by spray drying

\begin{tabular}{|c|c|c|c|c|c|c|c|}
\hline \multirow[b]{2}{*}{ Sample ${ }^{1)}$} & \multicolumn{7}{|c|}{ Sensory evaluation } \\
\hline & Appearance & Color & Flavor & Taste & Texture & hardness & $\begin{array}{c}\text { Overall } \\
\text { acceptability }\end{array}$ \\
\hline NTS & $4.60 \pm 2.01^{\mathrm{ab} 2)}$ & $4.70 \pm 1.77^{\mathrm{b}}$ & $3.60 \pm 1.51^{\mathrm{a}}$ & $3.60 \pm 1.51^{\mathrm{a}}$ & $2.90 \pm 1.37^{\mathrm{b}}$ & $3.10 \pm 1.60^{b}$ & $3.60 \pm 1.35^{c}$ \\
\hline Con & $3.40 \pm 1.90^{\mathrm{b}}$ & $3.70 \pm 1.70^{\mathrm{b}}$ & $3.10 \pm 1.45^{b}$ & $2.20 \pm 1.40^{b}$ & $1.80 \pm 1.32^{b}$ & $2.20 \pm 1.62^{b}$ & $2.40 \pm 1.17^{\mathrm{d}}$ \\
\hline LP-B10 & $5.80 \pm 1.23^{\mathrm{a}}$ & $5.60 \pm 1.17^{\mathrm{a}}$ & $5.60 \pm 1.35^{\mathrm{a}}$ & $4.40 \pm 1.43^{\mathrm{a}}$ & $4.60 \pm 1.58^{\mathrm{a}}$ & $4.80 \pm 1.40^{\mathrm{a}}$ & $5.00 \pm 1.25^{\mathrm{ab}}$ \\
\hline LP-B20 & $4.90 \pm 1.79^{\mathrm{ab}}$ & $5.00 \pm 1.56^{\mathrm{a}}$ & $5.30 \pm 1.34^{\mathrm{a}}$ & $5.00 \pm 1.83^{\mathrm{a}}$ & $5.60 \pm 1.35^{\mathrm{a}}$ & $5.10 \pm 1.79^{\mathrm{a}}$ & $5.70 \pm 1.25^{\mathrm{a}}$ \\
\hline LP-B30 & $4.40 \pm 1.96^{b}$ & $3.40 \pm 1.58^{\mathrm{b}}$ & $3.30 \pm 1.42^{\mathrm{a}}$ & $4.30 \pm 1.34^{\mathrm{a}}$ & $5.20 \pm 2.10^{\mathrm{a}}$ & $5.10 \pm 1.52^{\mathrm{a}}$ & $4.40 \pm 1.43^{\mathrm{bc}}$ \\
\hline
\end{tabular}

${ }^{1)}$ NTS, rice flour 100\%; Con, spray-dried rice flour 100\%; LP-B10, add with rice flour included $L$ plantarum CGKW3 by spray-drying $10 \%$; LP-B20, add with rice flour included $L$ plantarum CGKW3 by spray-drying 20\%; LP-B30, add with rice flour included $L$ plantarum CGKW3 by spray-drying $30 \%$.

${ }^{2)}$ Means \pm SD ( $\mathrm{n}=3$ ) within each column (a-d) followed by the same letter are not significantly different $(\mathrm{p}<0.05)$. 


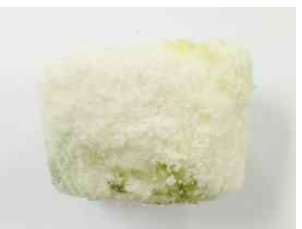

(A) NTS

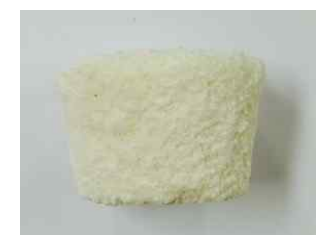

(B) Con

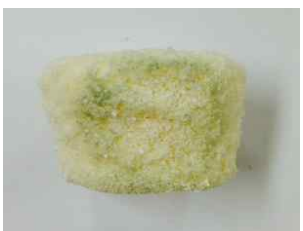

(C) LP-B10

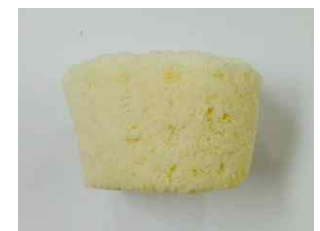

(D) LP-B20

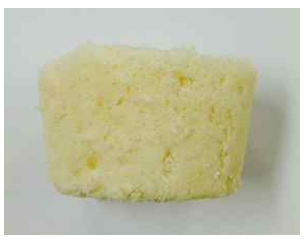

(E) LP-B30

Fig. 3. Observation of rice cake (Baekseolgi) produced during the storage for 6 days at room temperature $\left(25^{\circ} \mathrm{C}\right)$.

NTS, rice flour 100\%; Con, spray-dried rice flour 100\%; LP-B10, add with rice flour included $L$ plantarum CGKW3 by spray-drying 10\%; LP-B20, add with rice flour included L. plantarum CGKW3 by spray-drying 20\%; LP-B30, add with rice flour included L. plantarum CGKW3 by spray-drying $30 \%$.

서 가장 낮게 나타났다. 이는 $\mathrm{Con}$ 의 수분함량이 분무건조에 의해 무처리(NTS)보다 낮게 나타났으며, 색도는 LP-B30부 터 $\mathrm{b}$ 값은 증가하고 $\mathrm{a}$ 값은 감소하여 밝기가 어두워짐에 따라 기호도가 낮아진 것으로 판단된다. 이러한 경향은 향 및 맛에서도 같았다. 조직감 및 단단한 정도에서는 Con 및 NTS에 비해 유산균 포집 쌀가루를 첨가한 백설기의 기호도 가 모두 높은 평가를 받았다. 이는 Lee 등(26)의 쌀가루 분쇄 방법 및 입자 크기에 따른 백설기의 관능평가에서 수분함량이 높을수록 쫄깃한 정도가 높게 평가된다는 보고 로 미루어 볼 때, 본 평가 또한 수분 보수력 증가에 의해 전반적인 씹힘성이 개선된 것으로 사료된다. 전반적인 기 호도는 LP-B20에서 가장 우수하였고 Con에서 가장 낮게 나타났으며, Park 등(4)의 키토산과 천연 항균제제를 함유 한 백설기의 관능평가결과 약간 단단한 백설기가 기호성이 높은 경향을 나타내었다고 보고하여 본 연구결과와 유사하 였다.

\section{요 약}

본 연구에서는 우리나라 전통식품 중 하나인 떡의 대중 화 및 상품화를 위하여 김치로부터 분리된 Lactobacillus plantarum CGKW3이 포집된 쌀가루를 이용하여 관능 및 저장성이 향상된 백설기를 제조하고자 하였다. 유산균 포 집 쌀가루는 무처리 쌀가루 대비 각각 $10 \%(\mathrm{LP}-\mathrm{B} 10)$, 20\%(LP-B20) 및 30\%(LP-B30)를 첨가하여 제조된 백설기 의 수분함량 및 $\mathrm{pH}$ 는 각각 $33.39 \sim 36.70 \%$ 및 5.81 5.46이었 다. 색도는 유산균 포집 쌀가루에 의해 $\mathrm{L}$ 값은 감소하고, $\mathrm{a}$ 값 및 $\mathrm{b}$ 값은 증가하는 경향을 나타내었으며, $\triangle \mathrm{E}$ 값은 LP-B10에서 가장 낮게 나타났다. 조직감에서는 유산균 포 집 쌀가루 첨가량이 증가할수록 경도(931.37 1,222.67 $\left.\mathrm{g} / \mathrm{cm}^{2}\right)$, 응집성(8.96 10.58\%), 탄력성(31.41 34.48\%) 및 씹 힘성 $(42.46 \sim 62.37 \mathrm{~g})$ 이 유의적으로 증가하였다. 저장안정 성의 경우 LP-B20 및 LP-B30에서 $\mathrm{pH}$ 는 6 일간 유의적인 변화를 나타내지 않았으며, 미생물 안전성은 저장 2 일까지 일반세균이 발견되지 않아 저장안전성이 향상되었음을 확 인하였다. 관능평가 결과 유산균 포집 쌀가루를 첨가한 경 우 백설기의 외관, 색, 향, 맛, 조직감, 단단한 정도 및 전반적
인 기호도가 상승하였고, 특히 $20 \%$ 의 유산균 포집 쌀가루 를 첨가 했을 때 전반적인 기호도 및 저장성이 유의적으로 상승하였다. 따라서, 유산균 포집 쌀가루 첨가는 백설기의 관능 및 저장특성을 향상시키고 품질특성을 개선시켜 쌀 가공품의 다양성 및 상품화에 기여 할 수 있을 것으로 사료 된다.

\section{감사의 글}

본 연구는 산업통상자원부에서 지원하는 2014년도 지역 특화산업 육성 기술개발사업(No.R0002973)의 연구수행으 로 인한 결과물임을 밝힙니다.

\section{References}

1. Han JA (2009) Digestive, physical and sensory properties of cookies made of dry-heated OSA-high amylose rice starch. Korean J Food Sci Technol, 41, 668-672

2. Kum JS, Lee HY, Park JD (2011) Study of processing technology and product development for exportation of traditional rice product. KFREI 308005-3

3. Kim SS, Chung HY (2007) The texture and descriptive sensory characteristics of a Korean rice cake (Karedduk) with added emulsifier. Korean J Food Nutr, 20, 427-432

4. Park LY, Jeong EJ, Lee SH (2013) Effects of preservative containing chitosan and natural antimicrobials on quality and shelf life of Baeksulgi. J Chitin Chitosan, 18, 105-110

5. Jang EJ, Lee YK, Lee HG (1996) The study for consciousness, dietary life behaviors on Korean traditional food. Korean J Dietary Culture, 11, 179-206

6. Jang SY, Kim OM, Jeong YJ (2005) Quality characteristics of Baikseolgi added with the bacterial cellulose. Korean J Food Preserv, 12, 455-459

7. Brul S, Coote P (1999) Preservative agents in food. Mode of action and microbial resistance mechanisms. Int $\mathrm{J}$ Food Microbiol, 50, 1-17 
8. Sanglard D (2002) Resistance of human fungal pathogens to antifungal drugs. Curr Opin Microbiol, 5, 379-385

9. Cha SD, Yu JW, Kim TW, Cho HS, Lee DH (2012) Effects of Lactobacillus plantarum CIB 001 on lipid metabolism of hypercholesterolemic rats. Korean J Food Sci Technol, 44, 324-330

10. Shida K, Makino K, Morishita A, Takamizawa K, Hachimura S, Ametani A, Sato T, Kumagi Y, Habu S, Kaminogawa S (1998) Lactobacillus casei inhibits antigen-induced $\operatorname{IgE}$ secretion through regulation of cytokine production in murine splenocyte cultures. Int Arch Allergy Immnunol, 115, 278-287

11. Resta-Lenert S, Barett KE (2006) Probiotics and commensals reverse TNF- $a$-and IFN- $\gamma$-induced dysfunction in human intestinal epithelial cells. Gastroenterology, 130, 731-746

12. Klaenhammer TR (1988) Bacteriocins of lactic acid bacteria. Biochimie, 70, 337-349

13. Lee JH, Kim BK (2010) Effect of added sweet potato flour on the quality characteristics of the Korean traditional steamed rice cake, Backsulki. Food Eng prog, $14,135-145$

14. Kim Hy, Noh KS (2008) Effect of Trehalose on the shelf-life of Backsulgies. Korean J Food Cookery Sci, 24, 912-918

15. Shim EJ, An JH, Yu JH (1996) Studies on the effect of Lactobacillus delbrückii on the quality of bread. Korean Dairy Technol, 14, 85-95

16. Seibel W, Brummer JM (1991) The sourdough process for bread in Germany. Cereal foods world, 36, 299-302

17. Cha WJ, Lee JH, Lee SK (2007) Preservation of noodles adding the wheat flour ferment cultured by Lactobacillus acidophilus. Korean J Food Sci Technol, 39, 164-168
18. Cha WJ, Lee SK (2008) Effects of wheat flour ferment cultured by Lactobacillus acidophilus on the physical properties of cooked noodles. Korean J Food Sci Technol, 40, 321-325

19. Chang YE, Kim JS, Lee JH, Kim KM, Kim GC (2014) Quality characteristics of Korean pan-fried food (Jeon) added with lactic-fermented rice flour. J Korean Soc Food Sci Nutr, 43, 868-876

20. Yoon SJ (2007) Quality characteristics of Sulgitteok added with Lotus leaf powder. Korean J Food Cookery Sci, 23, 433-442

21. Kim CH (2009) Quality characteristics of Paeksulgi (Korean rice cake) containing various levels of whey protein isolate powder. Korean J Food Culture, 24, 561-569

22. Gerez CL, Carbajo MS, Rollan G, Torres LG, Font de Valdez G (2010) Inhibition of citrus fungal pathogens by using lactic acid bacteria. J Food Sci, 75, 354-359

23. Corsetti A, Gobbetti M, Rossi J, Damiani P (1998) Antimould activity of sourdough lactic acid bacteria: identification of a mixture of organic acids produced by Lactobacillus sanfrancisco CB1. Appl Microbiol Biotechnol, 50, 253-256

24. Choi HJ, Lee HW, Yoon S (2013) Fermentation of rice flour with Weissella koreensis $\mathrm{HO} 20$ and Weissella kimchii $\mathrm{HO} 22$ isolated from kimchi and its use in the making of Jeolpyeon. Korean J Food Cookery Sci, 29, 267-274

25. Kim YS, Park CR (2002) The microbiological quality estimation of samul chol-pyon during the storage. Korean J Soc Food Cookery Sci, 18, 46-51

26. Lee MG, Son SH, Choung MG, Kim ST, Ko JM, Han WY, Yoon WB (2015) Effect of milling methods and particle size on rice cake (Baeksulgi) characteristics. Food Eng prog, 19, 1-7 